\title{
Acute Kidney Injury Following Ingestion of Averrhoa bilimbi Juice
}

Md. Mostarshid Billah', Md. Anisur Rahman², Muhammad Abdur Rahim³, Ayesha Tabassum Swarna ${ }^{4}$, Palash Mitra ${ }^{5}$, Tufayel Ahmed Chowdhury ${ }^{6}$, Mehruba Alam Ananna ${ }^{7}$, Tabassum Samad ${ }^{8}$, Wasim Md. Mohosinul Haque ${ }^{9}$, Sarwar Iqbal ${ }^{10}$, Md. Abul Mansur ${ }^{11}$

\begin{abstract}
:
Bilimbi/belembu fruit belongs to the family of Oxalidacae, species Averrhoa bilimbi. Freshly prepared concentrated juice of bilimbi has very high oxalic acid content and consumption carries a high risk of developing acute kidney injury (AKI) by deposition of calcium oxalate crystals in renal tubules. AKI due to Averrhoa bilimbi juice injestion is very rare. We report the case history of a 60-year-old hypertensive, dyslipidemic patient, with normal renal function, who ingested around $600 \mathrm{ml}$ of juice in fasting state for treating dyslipidemia. The patient developed AKI and required three sessions of hemodialysis. Her renal function returned to normal after five weeks.
\end{abstract}

Key Words: Acute kidney injury, Averrhoa bilimbi, Hemodialysis

\section{Introduction :}

The bilimbi fruit (Averrhoa bilimbi) belongs to the family of Oxalidaceae and grows in tropical countries. The fruits are

1. Dr. Md. Mostarshid Billah, MBBS, FCPS (Medicine), Junior Consultant, Nephrology \& Dialysis, BIRDEM General Hospital, Dhaka

2. Dr. Md. Anisur Rahman, MBBS, MD (Nephrology), Junior Consultant, Nephrology \& Dialysis, BIRDEM General Hospital, Dhaka

3. Dr. Muhammad Abdur Rahim, MBBS, FCPS (Medicine), Assistant Professor, Department of Nephrology, BIRDEM General Hospital, Dhaka

4. Dr.Ayesha Tabassum Swarna, MBBS, Resident Medical Officer, Nephrology \& Dialysis, BIRDEM General Hospital, Dhaka

5. Dr. Palash Mitra, MBBS, Assistant Registrar, Nephrology \& Dialysis, BIRDEM General Hospital, Dhaka

6. Dr. Tufayel Ahmed Chowdhury, MBBS, FCPS (Medicine), Registrar, Department of Nephrology, BIRDEM General Hospital, Dhaka

7. Dr. Mehruba Alam Ananna, MBBS, FCPS (Medicine), Assistant Professor, Department of Nephrology, BIRDEM General Hospital, Dhaka.

8. Dr. Tabassum Samad, MBBS, FCPS (Medicine), Registrar, Department of Nephrology, BIRDEM General Hospital, Dhaka

9. Dr. Wasim Md. Mohosinul Haque, MBBS, MD (Nephrology), Associate Professor, Department of Nephrology, BIRDEM General Hospital, Dhaka

10. Dr. Sarwar Iqbal, MBBS, MD (Nephrology), Associate Professor, Department of Nephrology, BIRDEM General Hospital, Dhaka

11. Dr. Md. Abul Mansur, MBBS, Dip (Nephrology), Professor, Nephrology \& Dialysis, BIRDEM General Hospital, Dhaka

\section{Corresponding Author:}

Dr. Md. Mostarshid Billah

MBBS, FCPS (Medicine)

Junior Consultant, Nephrology \& Dialysis

BIRDEM General Hospital, Dhaka 1000, Bangladesh

Email: drbillah70@gmail.com cylindrical with five longitudinal lobes and measures from 4 to $10 \mathrm{~cm}$ [Figure I]. Probably it originates from the Moluccas Indonesia and is grown in India, Malaysia, Thailand and Bangladesh. ${ }^{1}$ Bilimbi (commonly known as bilimbi, belembu, cucumber tree, tree sorrel, Irumban Puli, or Chemmeen Puli) is a plant with several suggested medicinal properties. However, it has a high content of oxalic acid which could contribute to nephrotoxicity. ${ }^{2}$ By literature search we found only few cases of AKI due to bilimbi juice ingestion. ${ }^{3}$ In our country to the best of our knowledge no such reports has been published. We report a case in which a patient with previously normal renal function had AKI after bilimbi juice ingestion.

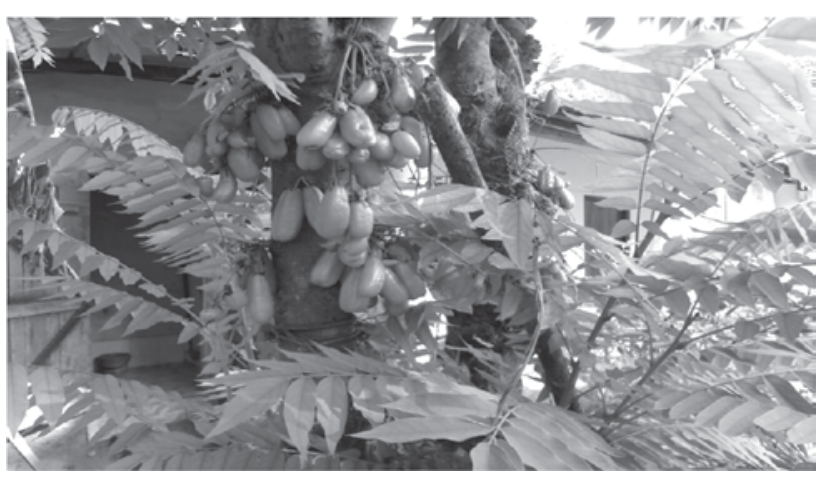

Figure: Averrhoa bilimbi fruit and tree

Case report:

A 60-year-old hypertensive lady presented with bilateral pedal edema, facial puffiness, anorexia, nausea and vomiting of six-day duration following ingestion of about $600 \mathrm{ml}$ of bilimbi juice. She had no history of hematuria or foamy urine, fever, dysuria, shortness of breath. She was detected to have dyslipidemia on routine evaluation one year back and was advised life style modification along with atorvastatin $10 \mathrm{mg}$ once daily. She was on regular follow-up and was documented to have normal renal function and high cholesterol level two months back. 
On examination, she had periorbital puffiness along with pitting bi-pedal edema and high blood pressure $(200 / 105 \mathrm{~mm}$ $\mathrm{Hg}$ ). She did not have retinopathy and other systemic examination including precordium and abdomen revealed normal finding.

Investigations showed serum creatinine of $5.5 \mathrm{mg} / \mathrm{dl}$, with normal hemogram and liver function tests. Urine analysis showed no albuminuria, haematuria and microscopy showed oxalate crystals. Ultrasound of abdomen revealed normal sized kidneys with normal cortical echogenicity and cortico-medullary differentiation. Other investigations are showed in table I.

After admission patient became oliguric (urine output $300 \mathrm{ml} / 24$ hours) and serum creatinine was increased to 7.1 $\mathrm{mg} / \mathrm{dl}$. She underwent three sessions of hemodialysis. Her urine output gradually increased to $3000 \mathrm{ml} /$ day six days after admission. She was discharged ten days later with serum creatinine of $2.0 \mathrm{mg} / \mathrm{dl}$ and three antihypertensive drugs (amlodipine $5 \mathrm{mg}$ daily, atenolol $50 \mathrm{mg}$ twice daily and prazosin $2 \mathrm{mg}$ thrice daily). She was on close monitoring \& her serum creatinine returned to normal by 5 weeks.

Table I: Laboratory investigations

\begin{tabular}{|c|c|c|}
\hline Investigation & Result & $\begin{array}{l}\text { important } \\
\text { reference }\end{array}$ \\
\hline Urine Protein & \multicolumn{2}{|l|}{ Nil } \\
\hline \multicolumn{3}{|l|}{ Deposits in Urine } \\
\hline Red blood cells ( $\mathrm{RBC}$ & \multicolumn{2}{|l|}{$0-1 / \mathrm{hpf}$} \\
\hline White blood cells (WBCS) & \multicolumn{2}{|l|}{$5-6 / \mathrm{hpf}$} \\
\hline Calcium oxalate crystal & \multicolumn{2}{|l|}{+} \\
\hline \multicolumn{3}{|l|}{ Blood } \\
\hline Hemoglobin & \multicolumn{2}{|l|}{$10.9 \mathrm{~g} / \mathrm{L}$} \\
\hline Total white blood cell count & \multicolumn{2}{|c|}{10300 cells $/ \mathrm{mm}^{3}$} \\
\hline Differential white blood cell count & \multicolumn{2}{|c|}{ P 70 L 23 E 7} \\
\hline ESR & \multicolumn{2}{|c|}{$17 \mathrm{~mm}$ I first hour } \\
\hline Platelet count & \multicolumn{2}{|c|}{$2.7 \mathrm{lakhs} / \mathrm{mm}^{3}$} \\
\hline Random blood sugar & \multicolumn{2}{|c|}{$5.5 \mathrm{mmol} / \mathrm{L}$} \\
\hline Blood urea & \multicolumn{2}{|l|}{$92 \mathrm{mg} / \mathrm{dl}$} \\
\hline Serum creatinine & $5.5 \mathrm{mg} / \mathrm{dl}$ & $0.6-1.4 \mathrm{mg} / \mathrm{dl}$ \\
\hline Serum sodium & $128 \mathrm{mg} / \mathrm{dl}$ & $135-145 \mathrm{mo} / \mathrm{l}$ \\
\hline Serum potassium & $4.3 \mathrm{mg} / \mathrm{dl}$ & $3.5-5 \mathrm{mmo} / 1$ \\
\hline Serum bilirubin total & \multicolumn{2}{|l|}{$0.4 \mathrm{mg} / \mathrm{dl}$} \\
\hline Serum alanine transaminase & \multicolumn{2}{|l|}{19 units/L } \\
\hline Serum aspartate transaminase & \multicolumn{2}{|l|}{34 units/L } \\
\hline Total protein & \multicolumn{2}{|l|}{$68 \mathrm{mg} / \mathrm{dl}$} \\
\hline Serum albumin & \multicolumn{2}{|l|}{$38.5 \mathrm{mg} / \mathrm{dl}$} \\
\hline Serum alkaline phosphatase & \multicolumn{2}{|l|}{$69 \mathrm{u} / 1$} \\
\hline Serum calcium & $8.5 \mathrm{mg} / \mathrm{dl}$ & $8.5-10.5 \mathrm{mg} / \mathrm{dl}$ \\
\hline Serum phosphorus & $4.0 \mathrm{mg} / \mathrm{dl}$ & $2.4-4.3 \mathrm{mg} / \mathrm{dl}$ \\
\hline Serum uric acid & $7 \mathrm{mg} / \mathrm{dl}$ & $2-6 \mathrm{mg} / \mathrm{dl}$ \\
\hline
\end{tabular}

\section{Discussion:}

A. bilimbi had been advocated for the treatment of hyperlipidemia, hypertension and diabetes by different communities. In Indonesia, the fruit is used to treat hypertension and the decoction of the leaves is used for the management of diabetes. ${ }^{4} \mathrm{~A}$. bilimbi is used as traditional medicine for treating cough, cold, itches, boils, rheumatism, syphilis, diabetes, whooping cough, and hypertension in Asia. ${ }^{5}$ Earlier studies showed that ethanolic leaf extract of $A$. bilimbi and its semi-purified fractions possesses hypoglycemic and hypolipidemic properties in type I diabetic rats when administered both intraperitoneally ${ }^{4}$ as well as orally. ${ }^{6,7}$ Oxalic acid content of bilimbi fruit has been reported to range between 8.57 and $10.32 \mathrm{mg} / \mathrm{g}$ with highest levels seen in half ripe fruit in rainy season and lowest levels in ripe fruits in dry season $(25.1 \mathrm{mg} / 100 \mathrm{~g}){ }^{2}$ Various renal and neurological side effects like muscle weakness, intractable hiccups, mental confusion, seizures after ingestion of star fruit (A. carambola) have been documented..$^{8-10} A$. bilimbi, which belongs to the same family, causing acute tubular necrosis due to high oxalate content has few case reports. Oxalic acid has a direct toxic effect on the renal tubules and interstitium, facilitates the development of oxalate crystals which are endocytosed by renal epithelial cells and promote a proliferative response. These crystals also stimulate specific genes in renal tubular cells, including the connective tissue growth factor gene leading to interstitial fibrosis. ${ }^{3}$

There is several case reports of acute oxalate nephropathy due to several agents described in the literature. Bakul et al had reported a series of cases from five hospitals in the state of Kerala, India who developed AKI due to acute oxalate nephropathy after consumption of bilimbi juice. In that series 7 out of 10 patients had dialysis requiring renal failure after intake of juice but fortunately all had renal recovery. ${ }^{3}$ Nair $S$ et al had reported 2 cases; both patients had complete renal recovery though one required dialysis support. ${ }^{11}$

Our patient was treated with 3 session of hemodialysis and her renal function returned to normal within 5 weeks. Renal biopsy may show oxalate crystal in renal tubule ${ }^{3,11}$ but in this case as patient present lately and patient didn't comply with medical decision of renal biopsy so we couldn't go for renal biopsy. Serum oxalate levels could not be assessed in our patient as the facility was not available in our hospital.

\section{Conclusion:}

Bilimbi when used in high concentrations especially in empty stomach or dehydrated state, the fruit juice can lead to AKI due to acute tubular necrosis, owing to its high oxalate content, which results in intratubular oxalate crystal deposition. We conclude that patients with CKD not yet on dialysis and all patients on dialysis should be warned to avoid eating bilimbi. Individuals with normal renal function should be warned to avoid ingestion of large amounts of the bilimbi or juice especially in an empty stomach. 


\section{References :}

1. Morton JF. Bilimbi (Averrhoa bilimbi). In: Morton JF editor. Fruits of warm climates. Winterville: Creative Resources;1987. p.128-9.

2. De lima G, de Almeida ME, and dos Santos LL, "Physicochemical characteristics of bilimbi (Averrhoa bilimbi)," Revista Brasileira de Fruticultura 2011; 23(2): 421-23.

3. Bakul G, Unni VN, Seethaleksmy NV, Mathew A, Rajesh R, Kurien $\mathrm{G}$ et al. Acute oxalate nephropathy due to 'Averrhoa bilimbi' fruit juice ingestion. Indian J Nephrol 2013; 23: 297-300.

4. Tan BK, Tan CH, Pushparaj PN. Anti-diabetic activity of the semi-purified fractions of Averrhoa bilimbi in high fat diet fed-streptozotocin-induced diabetic rats. Life Sci. 2005;76:2827-39.

5. Goh SH, Chuah CH, Mok JSL, Soepadmo E. Malaysian medicinal plants for the treatment of cardiovascular diseases. Pelanduk, Malaysia, 63.

6. Pushparaj P, Tan CH, Tan BKH. Effects of Averrhoa bilimbi leaf extract on blood glucose and lipids in streptozotocin-diabetic rats. Journal of Ethnopharmacology 2000;72, 69-76.
7. Pushparaj PN,Tan BK, Tan CH. The mechanism of hypoglycemic action of the semi-purified fractions of Averrhoa bilimbi in streptozotocin-diabetic rats. Life Sciences 2001;70, 535-47.

8. Da Costa JA, Garcia-Cairasco N, Netto JC, Nakagawa B, Dantas M. Intoxication by star fruit (Averrhoa carambola) in 32 uraemic patients: Treatment and outcome. Nephrol Dial Transplant 2003;18:120-25.

9. Neto MM, Robl F, Netto JC. Intoxication by star fruit (Averrhoa carambola) in six dialysis patients? (Preliminary report) Nephrol Dial Transplant 1998;13:570-72.

10. Annana MA, Iqbal S, Samad T, Rahim MA, Haque WMM, Chowdhury TA et al. Nephrotoxicity caused by Star Fruit ingestion in 20 patients and their outcome: An Experience from Bangladesh. Nephrol Dial Transplant 2015; 30 (suppl 3): S 440-S471

11. Nair S, George J, Kumar S, and Gracious N, "Acute Oxalate Nephropathy following Ingestion of Averrhoa bilimbi Juice," Case Reports in Nephrology, 2014; Article ID 240936, 5 pages, 2014. (accessed May 13, 2015). 